\title{
Oman's Labour Force: An Analysis of Gender in Management Roles
}

The Sultanate of Oman (henceforth referred to as Oman) has been described in the past as "one of the most traditional societies in the Arab world" (Curtiss, 1999, p. 66), and the Arab world itself comprises some of the most traditional societies within the world. Some progress has been made in the past few decades in terms of the involvement and advancement of women within workplaces and society at large. According to the Oman Statistical Year Book (National Center for Statistics and Information, 2011b), political leaders in Oman have recently shown a strong commitment to women's rights and empowerment. Women occupy $9 \%$ of the senior positions among Omani civil service employees and $15.5 \%$ of the seats in the Upper House or Senate; nine women hold ministerial positions (CountryWatch, Inc., 2012; Hausmann et al., 2011). In fact, Oman is among the Middle East countries that have shown at least some improvement in their Global Gender Gap index score, which rates countries from 0.00 (inequality) to 1.00 (equality). However, despite the improvement, in 2011 Oman was still ranked 127 of 135 countries and was given a 0.587 score. Yet conditions are continually changing, and academic research that focuses on understanding the status of women in Oman's more modernised society is needed more than ever (Mernissi, 2003). Chatty (2000) acknowledges the importance of such additional research, as "women in the Middle East have come to be seen as political and economic actors," pushing the boundaries of what is acceptable, as defined by a "patriarchal state" (p. 241).

Research on women managers and leaders in Oman is limited, and studies that create a baseline to measure future improvements are particularly valuable. Hence, authors designed a study to establish this baseline by investigating the presence (or absence) of women in senior and managerial roles in the private sector through a quantitative gender analysis of 122 private and publicly listed companies. The focus on the private sector was chosen as there is a 
paucity of literature about women employed in this sector in the Middle East and North Africa (MENA) region. Other researchers (e.g., Davis, 2012; Dechant and Al Lamky, 2005; Khan and Almoharby, 2007; McElwee and Al-Riyami, 2003; Al-Sadi et al., 2011) have already studied self-employed and entrepreneurial women in the region. In addition, accurate data on women managers and leaders in the public sector are difficult to secure. For this study, the roles located within the organisations (e.g., board members, chief officers, vice presidents, top management, division or unit heads) were analysed for gender comparison with various demographic variables. ${ }^{1}$

\section{Literature Review}

In the 1970s, Oman's new monarch, His Majesty Sultan Qaboos bin Sa'id al Sa'id, implemented a process of modernisation through personal and direct intervention (Shaw, 2001) that involved women who were employed in both the public and private sectors (AlQudsi, 1998; Chatty, 2000). As such, the working woman became a symbol of a modern state and was considered a necessary human resource to increase economic growth. But, as happened in other countries, once an immediate economic need had been met, women were discouraged from "particular occupations deemed inappropriate for the female sex" (Chatty, 2000, p. 244). In general, employment, management, and leadership for women in Oman have been influenced by a host of complex variables, including cultural and religious values. The remainder of the literature review highlights literature in the following three categories: societal values and influences, government policies and organisational practices, and the current presence and status of women in the Omani private sector.

\section{Societal Values and Influences}

\footnotetext{
${ }^{1}$ Authors have completed a similar study on the United Arab Emirates (Kemp et al., 2013), are in the process of analyzing data for the four additional countries within the Gulf Cooperation Council (GCC), and will conclude with a comparative study of the six GCC countries analysed.
} 
The reasons for low female employment and status in Omanian organisations may be framed as cultural, societal, and/or religious. Clearly, there remains a strong belief that certain jobs inside and outside the home are for men and others are for women (Metcalfe, 2006). Robertson et al. (2001) state that generalizations about gender and ideas and notions about the traditional role of women in society have hindered the advancement of female managers around the world; however, these are "perhaps even more pronounced in the Arab Gulf region because of the prevailing strict Islamic traditions” (p. 231). Metcalfe (2006) observes that many women who are employed are not challenging their Islamic values, rather, they view working as "part of the long-term development of a just and fair Islamic nation" (Metcalfe, 2006, p. 103), yet many do not share their perspectives.

One societal aspect that has contributed to the growth of women in the workforce is the increase in education opportunities in the past few decades. Most studies show that when women complete college, they are more likely to be employed (CountryWatch, Inc., 2012, p. 136). Academic qualifications are considered to be a route to gaining better positions in work, a belief held more firmly by Omani females than males (Al-Harthi, 2011). However, a poor employment market is anticipated to continue in Oman, as "the annual number of college and university graduates already exceeds the annual number of jobs available in Oman" (AlBarwani et al., 2009, p. 416). Fewer jobs available inside the country causes graduates to seek work elsewhere, but the opportunity for emigration is less likely for women than for men because of cultural restrictions on women travelling or living away from the family. That is, travel for work purposes is limited, as there may be little support women working due to seeming role conflicts between employment and family obligations (Hutchings et al., 2010; Metcalfe, 2006). The gap between highly educated women and their presence in employment is noted by Elnaggar (2008), who concludes that many educated women are seeking 
employment. Al-Lamki (2002) points out the need for higher education to be aligned with market needs to strengthen the Omani economy. Oman loses labour market potential because of the unemployment or underemployment of qualified, educated women.

Females in gender-marginalised occupations may also have limited employment possibilities because of traditional workplace practices. Gender segregation at work is considered appropriate, but this practice prevents women from working in mixed environments, such as engineering firms (Al-Harthi, 2011). Other potential growth areas for Oman's economy include those that would advance the country in the global knowledge society. Again, organisational constraints may minimize participation of Omani women, who "are at a higher risk of being marginalized from today's knowledge-based economy, due to factual findings related to a traditionally male-dominated ICT sector" (Elnaggar, 2008, p. 280). Certain jobs are then less available to local women, and expatriate women and local men typically fill those positions.

Another unique barrier for Omani women is that, according to a recent report, the ability of women to participate in the employment market depends on where they live. Those in the capital, Muscat, experience "the most freedom, working in the retail sector and hotels, and as policewomen, doctors, nurses and civil servants" (Economist Intelligence Unit, 2010, p. 11). Away from the capital, "women may be restricted to jobs in which they only come into contact with women and girls, such as teaching in a girls' school or nursing female patients. Once married, they may be prevented from working at all” (p. 11).

Assumptions about the definitions and understanding of leadership and authority may also create barriers and opportunities for people in Oman. First, Common (2011) states that, in Oman, the word leadership is immediately linked to the Sultan and is not associated with business leaders. Second, Porcaro (2011) finds that Omani men value authority more than 
women do because males have more direct involvement with authority figures. Karabenick and Moosa (2005) also find that Omani women college students were less accepting of authority than males, concluding that female study participants were high achievers, independent thinkers, and more accomplished in general because they had already overcome societal barriers to success (p. 390). Third, a tendency for bureaucracy is common in Arab management, but a survey of female students also notes that the values of leadership in Oman are based on charisma, interaction, and a strong rational legal authority (Common, 2011, 2012; Neal et al., 2005). It is important to note, however, that these data are limited by participants' lack of exposure to the working environment - particularly on the part of the women.

\section{Government Policies and Organisational Practices}

A royal decree in 1996 is of particular significance for employment studies in Oman (Ministry of National Economy, 1996). The Vision for Oman's Economy: Oman 2020 or Vision 2020 moves the country away from reliance on the public sector to building the economy via private sector enterprise (Ghailani and Khan, 2004). Omanisation is a law of positive discrimination, within which employers are expected to achieve recruitment targets in favour of nationals' employment (Al-Lamki, 2005; Goveas and Aslam, 2011; Khan and Almoharby, 2007; Khan, 2010). Interestingly, foreign investment in the GCC countries is welcomed and continues even as Oman strives for Omanisation within its labour force (Mellahi et al., 2003). In Vision 2020, there is no specific reference to the future of women in the labour force, but Budhwar et al. (2002) suggests that the programme does encourage females to enter into employment. However, these authors also state that the anticipated skills development has lagged behind the national goals. There is some evidence that Omanisation has positively affected women's employment. In the banking industry, one-third of the 
employees are women. According to Al-Lamki (2005), “This is the highest female employing sector and represents almost fifty nine percent of the total female employees employed by the private sector in the country" (p. 183).

In 2010, the Omani government and the International Labour Organization (ILO) created a strategy document to advance women in employment (ILO, 2010). Prior to this, Lalji (2006) states, the principles and rights at work declared by the ILO stipulated "the elimination of discrimination in the workplace" (p. 12). The Decent Work Program, as it is termed, is "to enhance decent and productive job opportunities for women in conditions [of] freedom, justice and dignity" (Goveas and Aslam, 2011, p. 234). The strategy devised by the government and the ILO is for research to be undertaken to identify best practices to support women's involvement in the labour force and for equal opportunities to inform national policy (ILO, 2010).

There are numerous examples of labour laws being based on religious beliefs that restrict local women's working in various professions. First, one Omani law states that "women shall not be required to perform works which are harmful to the health or hard works or such other works as may be specified by a decision of the Minister" (Article 82, Ministry of Manpower, 2012). Nursing is an example of an occupation that is considered to be a respectable profession for women in other countries, but not in a Majority Muslim Country (MMC) such as Oman. Nursing is perceived as a low-level rather unclean job (Abugideiri, 2012; Maben et al., 2010), and because the law and societal values take this stance, nursing jobs are typically staffed by expatriate women. Second, there are legal restrictions on women working night shifts; reasons are attributed to personal protection, but the law also confines women to employment between 6:01 a.m. and 7:00 p.m. (Article 81, Ministry of Manpower, 2012). Of course, this law limits women's choices, as many private 
sector occupations staff a variety of shifts. Third, under Article 83, "a woman who has completed a year in the service of the employer shall be entitled to maternity leave the total of which shall not exceed six weeks" (Ministry of Manpower, 2012). A consequence of that law, Al-Harthi (2011) reports, is that "most employers, both public and private, prefer to employ males to avoid what they see as frequent maternity leaves" (p. 546). Personal and societal choice for a nurturing role, combined with a lack of organizational support, disadvantages women in the promotion stages. The result is a low percentage of women in senior positions and a consequent capping of women's earning potential. In fact, most Omani women achieve their peak economic activity before they reach the age of 30 . Many find it difficult to reconcile the contrasting values and policies that appear to protect and discriminate.

Organisational practices are also purported to account for at least some of the reasons women remain underrepresented in the Omani workplaces, particularly within the management and leadership ranks of the country's largest companies. Four examples from the literature provide insight into this phenomenon. First, Al-Lamky (2006) states that these practices negatively affect women's rise to seniority as their jobs remain “concentrated primarily in clerical and administrative jobs" (p. 51). These jobs tend to be clustered at the lower end of organisational hierarchies, and potential advancement to senior positions is minimal. Second, in their research with 100 female managers in the Middle East, Hutchings et al. (2010) find that organisational policies tended towards resistance to women taking international assignments, which has become important for promotions in most global companies. This study also reports that less gender diversity in companies is caused by a lack of attention to gender equality, which leads to few female role models and little training for women. Next, mentoring and sponsorship by influential men in companies is required for 
more women to be developed and promoted within workplaces, and this remains a challenge within the Omani culture. Finally, Shaw (2001) writes that access to occupations in the MENA region has been controlled by a range of factors, including "gender, tribes and family networks, 'wasta' and patronage” (p. 103). Tlaiss and Kauser (2011) state that a barrier to many women is a lack of wasta, described loosely as an influential network or connections for recruitment, training, and promotion to senior positions. They argue that women are prevented in two ways from building these connections: 1) a lack of professional connection with men because of segregation, and 2) few women at the top to support others further down the hierarchy.

It is important to note that Oman's workforce is dissimilar to other countries in the GCC, as the national population undertakes basic work (e.g., cleaners), and they are employed in customer-facing positions in the retail and travel industries (Curtiss, 1999). Conversely, Neal (2010) states that women "work across many sectors of the Gulf economies, often at senior levels" (p. 248). CountryWatch Inc. (2012) confirms that "educated women in Oman now occupy many middle and upper level positions in all sectors of society" (p. 136). But this accounts for only $10 \%$ of the senior positions, classified as "legislators, senior officials and managers" by the World Economic Forum (Hausmann et al., 2011). Females in Oman fare better in lower-status positions, as "professional and technical workers," where there is nearly parity in numbers with males.

\section{Current Presence and Status of Women-Private Sector}

Oman is a small country with a total population of almost 3.3 million; this includes approximately two million Omanis, who are referred to as locals, nationals, or citizens (National Center for Statistics and Information, 2010), and 1.3 million expatriates. There are approximately equal numbers of national women and men. The private sector employs 
177,716 citizens, of which 34,234 are women (National Center for Statistics and Information, 2011b). However, in a one-year timeframe there was a 17\% increase of Omani women working in the private sector, from 29,273 (2009-2010) to 34,234 (2010-2011) (National Center for Statistics and Information, 2011a). Interestingly, although there is a lower percentage of Omani women working in the private sector $(19 \%)$ than in the public $(43 \%)$, the employment situations for Omani men is reversed (National Center for Statistics and Information, 2011b).

In the private sector, banking is the most popular industry for women in Oman, with $40 \%$ of the national labour force being female (National Center for Statistics and Information, 2011b). Although salaries for the banking industry were not obtained, the average monthly salary for Omanis employed in the private sector is $\mathrm{RO} 228,{ }^{2}$ and women are paid slightly below this average at RO 222 per month, with the highest number clustered within the lowest wage group (National Center for Statistics and Information, 2011b). Furthermore, the peak in earning for Omani women in the private sector is between 400 and $500(\mathrm{RO})$, with women being just over a quarter of that workforce in this salary range. From that point, as salaries increase, there is a noticeable decline in the numbers of Omani women employed. The total population of Omani women in the 25-29 age group is 102,679, and that is the age group in which we find the highest number of employed women $(9,876)$, which is $10 \%$ of the available population (National Center for Statistics and Information, 2011b). From that age group onwards the number of women reduces in the private sector workforce. Like other GCC countries, Oman has a large number of expatriates (Al-Sayegh, 2012; Kuehn and Al-Busaidi, 2000), and although there is gender parity among the Omani, females

\footnotetext{
21 Omani Rial $(\mathrm{RO})=\mathrm{US} \$ 2.6 ; 228$ Omani Rial (RO) = US\$594; 120 Omani Rial (RO) = US\$312 http:// www.oanda.com/currency/converter/ (accessed 19 February 2013).
} 
comprise only a third of the expatriate population. Most expatriates are single men who reside in Oman for work purposes; some single female expatriates with work visas and spouses (usually female) of expatriates may also be included in the labour market. There has been a small increase $(6 \%)$ in female expatriates in private sector employment (National Center for Statistics and Information, 2011a). In the private sector, expatriate females make up more than half of the expatriate employees in health and social work, and they are nearly half of the expatriate labour force in education. The vast majority of expatriate women (nearly $80 \%$ ) are employed as maids or nannies in private households (National Center for Statistics and Information, 2011b). In the senior ranks of private sector organisations (i.e., administration, directors, and managers) there are only 1,459 female expatriates, which is $5 \%$ of the total number of expatriates.

As figures show, there has been an increase in Omani women employed in the private sector and a lesser increase in expatriate women. This indicates that although the Omanisation policy may not be targeted particularly at women, it has increased their private sector employment. However, little has been documented regarding the numbers of women in specific management and leadership positions within the private sector, particularly in different sectors and company sizes, although Hawkamah (2012) does document that there are eight women directors on the boards of corporations listed in the Muscat Securities Markets. A review of the literature demonstrates the need for a specific study that assists future researchers by creating a baseline by investigating the presence (or absence) of women in senior and managerial roles in the private sector.

\section{Research Methods}

The research is based on data available from the Zawya database, which tracks information about companies in the MENA region. Zawya is a major online business 
intelligence platform that provides detailed profiles on companies, as well as industry and asset class research, online networking, and news (Zawya, 2013). For this study, the original list of possible data categories available for analysis include country, location of investments, sector, ownership types, company size, market capital, total revenue, total revenue growth, total assets, total assets growth, net profit, net profit growth, and company profile, officers, and news. However, fewer than 10 percent of the companies analyzed had entries on market capital, total revenue, total revenue growth, total assets, and total asset growth, net profit, and net profit growth. Hence, these variables were from dropped from the study, which, unfortunately, limited our use of more advanced statistical techniques to analyze the remaining data.

In January 2013, Zawya listed 938 privately-owned organisations in Oman. We limited our study to those with 300 or more employees, and $16 \%$ of these companies $(n=122)$ met this criteria. ${ }^{3}$ Hence, this quantitative gender analysis includes $12 \%$ of all companies in the database. The data were prepared manually for analysis by research assistants trained by one of the authors. The variable categories were created for each organisation, including position, number of employees, industry classification, and ownership. The raw numbers relating to these categories were coded appropriately. The most time-consuming data preparation element related to categorizing and coding the gender of the senior personnel within the companies. The Zawya database includes names of these senior personnel divided into board members, senior managers, key officers, and heads and department managers.

Titles such as Chief, Director, Vice President are given, and the name data also includes role

\footnotetext{
${ }^{3}$ We are in the process of conducting research on each Gulf country and have set the same criterion for each study.
} 
designation (i.e., departmental responsibility). The data on gender of each individual manager and the totals were manually entered for each company.

Research assistants determined the gender of individuals in the sample from the listed designations given in the Zawya database. "Mr.," "Ms.," or "Mrs.," and other titles designated the gender of personnel. In the GCC, the title of Sheikh (male) or Sheikha (female) indicates gender, although in the Oman data only "Sheikh" appeared. Other titles given in the database are gender neutral. One title is Dr., which was checked for female names. We assumed H.E. was a gender-neutral title; however, only males (His Excellency) were found. Similarly, H.H. (we assumed Her/His Highness) was actually defined only as His Highness (Prince/Sheikh). Where occasionally the title was missing, or there appeared to be an error, research assistants assigned the gender based on their knowledge of regional names. If the gender could not be assigned based on this local knowledge, the company website or professional network (LinkedIn) was consulted. If gender could not be determined using these tactics, lists of common names for nationalities were consulted.

\section{Findings}

Data emerged to reveal where the female top leaders are located within organisations by position (e.g., board members, chief officers, vice presidents, top management, division or unit heads). The results were then compared with pertinent demographics: sector, number of employees, and ownership. The descriptive results are shown in the following tables according to position, sector, number of company employees, and ownership:

$$
\text { [Insert Table } 1 \text { about here] }
$$

Rank Order By Position:

1. Department heads (12.5\%)

2. Top marketing, sales, communication, corporate affairs, brand, and circulation $(11.9 \%)$ 
3. Top HR positions $(10.3 \%)$

4. Directors $(8.3 \%)$

5. Board members $(5.5 \%)$

6. General managers $(3.1 \%)$

7. Top management $(3.0 \%)$

8. Top positions in finance, banking, investor relations, and wealth $(2.3 \%)$

9. Regional/branch/division/unit heads and managers (1.0\%)

10. Top operations, turbocharge, strategy, and commercial positions $(0.9 \%)$

11. Chief officers - CEO, CFO, COO $(0.7 \%)$

12. Vice presidents $(0.0 \%)$

13. Top IT/data/information positions $(0.0 \%)$

14. Top administration $(0.0 \%)$

15. Top business development/head branch positions $(0.0 \%)$

[Insert Table 2 about here]

Rank Order by Sector:

1. Transport (transport) $(7.8 \%)$

2. Finance (financial services, Islamic finance) $(7.3 \%)$

3. Pseudo Services (education, government, healthcare, services, legal) $(5.7 \%)$

4. Technology (IT, media, telecom) (4.2\%)

5. Hospitality (leisure and tourism, food and beverage) (4.1\%)

6. Industry (agriculture, construction, manufacturing, mining and metal, oil and gas, power and utilities) $(2.9 \%)$

7. Sales (consumer goods, real estate, retail) $(2.4 \%)$

[Insert Table 3 about here]

Rank Order by Number of Company Employees:

1. 1000-2499 employee companies (7.1\%)

2. $5000+$ employee companies $(5.4 \%)$

3. 300-499 employee companies (4.7\%)

4. 500-999 employee companies $(2.6 \%)$

5. 2500-4999 employee companies $(2.4 \%)$

[Insert Table 4 about here]

\section{Discussion and Implications}

Not surprisingly, the data show that there are fewer women than men employed in management positions in Oman and that women are substantially underrepresented in senior roles. This study found that females hold $5.7 \%$ of the top department leadership positions 
within the 122 companies, the highest percentages being with department heads $(12.5 \%)$; top project management positions (11.9\%); top marketing, sales, communication positions (11.9\%); and top human resource positions (10.3\%). There were no women represented in any company in top IT/data/information, administration, legal, or business development/head branch position posts. A lower percentage (4.2\%) of female representation was found in the ranks of senior company leaders, with the highest being directors $(8.3 \%)$ and the two with no representation being vice presidents and key officers. It appears that 5.5\% of corporate board members in this 2013 study were female, which is up from the $2.1 \%$ reported in the Dubai Women Establishment (2011) Outlook report using 2007 data from TNI Investment Research. However, the same report touted that $9 \%$ of "legislators, senior officials, and managers" in 2008 were female, while the Global Gender Gap report (Hausmann et al., 2011) the femaleto-male ratio for this same group was 0.10 . The current study, however, found that a combined total of $4.5 \%$ existed in female representation in senior and top department roles in Omani companies with 300 or more employees. Although these comparisons have been provided, caution should be used as the study populations and samples for each are substantially different.

Surprisingly, the highest percentages of female managers and leaders in the Omani companies were found in the finance (7.3\%) and transport (7.8\%) industries. At first glance, these two industries seem to be male-dominated professions; however, as previously mentioned, women are found in higher numbers within the banking industries, which could account for the finance percentage. A focus on their employment in company practice, following government policy, has enabled women to increase their senior status within this industry. In addition, a few female-friendly companies within the country could have made a difference in the higher numbers, as only 11 companies were analyzed in finance and 14 in 
transport. Interestingly, the sectors with the lowest percentages of females in management included sales $(2.4 \%)$ and industry $(2.9 \%)$. Female employees in general are found in higher numbers in hospitality and pseudo services (e.g., education, government, healthcare, services), yet the percentage of females in top positions is still low ( $4.1 \%$ and $5.7 \%$, respectively). Many senior roles for women are found in occupations in which women can more freely work with men, such as marketing and human resources.

There appears to be no pattern in terms of the percentage of female leaders and the size of company in terms of employees. One may expect there would be more women in smaller companies (i.e., 300-499) and fewer in larger ones (i.e., 5000+); however, this was not the pattern in our study. The lowest numbers were companies with 500-999 employees $(2.6 \%)$ and $2500-4900(2.4 \%)$ and the highest in companies with 1000-2499 employees (7.1\%). It is also important to note that a percentage of the females in the "senior ranks" of private sector organizations in Oman are expatriates (National Center for Statistics and Information, 2011b). This means that the percentages outlined in our study include both nationals and expatriates, which should be considered when using these data as they relate to company size or any study variable.

We also analyzed data in terms of ownership (private or public) by position. Slightly more women were found in the ranks of private $(4.6 \%)$ versus public $(3.6 \%)$ in terms of the percentage of female senior leaders, while it was reversed in the top department leader category $(7.3 \%$ public; $4.8 \%$ private). Clearly, there are substantially fewer women in management and leadership roles than men, whether data are analyzed by position, sector, company size, or ownership. Yet, the data provide a better understanding of the current state of affairs, which is a starting point for future benchmarking and research. 
The study suggests a number of important implications to practice. First, Omanian colleges and universities should design and develop partnerships, programs, and curriculum geared toward exposing female students to workplaces, including private-sector employers. Student exposure through field trips, internships, mentoring, and role models in the private sector will increase their knowledge of the working environment and potential challenges and opportunities within various types of companies. Second, it is clear that employment policies with Omanian companies need to be revisited in order to increase the recruitment, retention and promotion of women in the private sector. To retain women in the workforce for longer periods, and for them to be available for promotional opportunities, a range of flexible working arrangements is needed, including part-time employment, flexible working times, and teleworking. Finally, Syed (2010) calls for awareness training in organisations to support women's future in employment. Training is essential for expatriate and local workers to understand each other and work together. International managers need to be sensitized to the workings of different cultures, and the development of their "relational or "soft skills"” may help to overcome reservations about dress, attitude, work ethics, and family values that are particularly helpful in recruiting, retaining, and promoting women (Harris and Kumra, 2000, p. 604). Training and development of women for senior status within the private sector is also warranted to increase their presence.

A number of recommendations for future research emerge from this study as well. Further descriptive research needs to be conducted on the variables in this study (i.e., sector, industry, company size) as well as a host of other variables (e.g., total revenue, total revenue growth, company family-friendly policies and practices, numbers in terms of nationals and expatriates). To move forward with research it is essential that complex quantitative data be collected so advanced statistics can be run to discover more insight through investigating 
correlations, relationships, and links among variables. Qualitative studies are also needed to understand the experiences of top women leaders and their pathways to becoming leaders in their cultural contexts. Exploring the details of successful company programs, interventions, initiatives, and strategies is also of utmost value to companies for proactive management of diversity. Academic study should also investigate the perceptions and realities around recruitment, retention and promotion of women in Oman. Finally, exploring the aspirations and motivations of women to be managers and leaders is a foundational project that would be helpful in understanding the starting point for Omani women to work and lead.

\section{Conclusion}

The authors designed this descriptive study to create a baseline for researchers and practitioners by investigating the presence (or absence) of women in senior and managerial roles in the Omani private sector. Research on women managers and leaders in Oman is limited, and this study fills a gap by providing a snapshot of the state of affairs of women in corporate leadership. By doing so, we add to the extant academic literature on the managerial and leadership status of women in Oman (Al-Hamadi et al., 2007; Al-Lamky, 2006), as this is one of the first known scholarly studies conducted on the topic as it relates to specific positives, sectors, and industries. However, the major limitation of this study was that, because of the limited data variables available in the database utilized, the statistical analysis provided was descriptive in nature and lacked advanced statistical techniques for comparison and relationship analysis. Yet, quantitative data would have been nearly impossible for researchers to gather in other ways because of limited access to women in employment due to their small numbers, respect for their privacy, and, although English is the language of business, the authors do not speak the native language (Arabic). 
Nonetheless, this study has endorsed previous findings on women's employment in Oman, and it adds quantitative data to the body of knowledge about women's progress in the private sector. This research increases the academic knowledge on international issues in gender and management in its focus on a country within the GCC and the wider MENA region. It also provides helpful insights for educators, scholars, practitioners, and government leaders who work to help prepare women for leadership positions in this important region. The authors believe it is important for Omani females to develop more management and leadership skills so they can become more effective role models for the next generation of female workers. 
Table 1: Position—Business Leaders in Oman Companies by Gender

\begin{tabular}{|c|c|c|}
\hline Category & $\begin{array}{l}\text { Males } \\
\text { No. }(\%)\end{array}$ & $\begin{array}{l}\text { Females } \\
\text { No. }(\%)\end{array}$ \\
\hline \multicolumn{3}{|l|}{ SENIOR COMPANY LEADERS } \\
\hline Board members & $497(94.5)$ & $29(5.5)$ \\
\hline Top management & $935(97.0)$ & $29(3.0)$ \\
\hline Key officers* & $8(100.0)$ & $0(0.0)$ \\
\hline Regional/branch/division/unit heads and managers & $99(99.0)$ & $1(1.0)$ \\
\hline Chief officers - CEO, CFO, COO & $135(99.3)$ & $1(0.7)$ \\
\hline General managers & $157(96.9)$ & $5(3.1)$ \\
\hline Vice presidents & $15(100.0)$ & $0(0.0)$ \\
\hline Directors & $342(91.7)$ & $31(8.3)$ \\
\hline TOTAL & $2188(95.8)$ & $96(4.2)$ \\
\hline \multicolumn{3}{|l|}{ TOP DEPARTMENT LEADERS } \\
\hline Department heads & $63(87.5)$ & $9(12.5)$ \\
\hline $\begin{array}{l}\text { Top positions in finance, banking, investor } \\
\text { relations, and wealth }\end{array}$ & $84(97.7)$ & $2(2.3)$ \\
\hline Top HR positions & $61(89.7)$ & $7(10.3)$ \\
\hline Top IT/data/information positions & $37(100.0)$ & $0(0.0)$ \\
\hline $\begin{array}{l}\text { Top marketing, sales, communication, corporate } \\
\text { affairs, brand, and circulation }\end{array}$ & $52(88.1)$ & $7(11.9)$ \\
\hline $\begin{array}{l}\text { Top operations, turbocharge, strategy, and } \\
\text { commercial positions }\end{array}$ & $115(99.1)$ & $1(0.9)$ \\
\hline Top project management positions* & $7(87.5)$ & $1(12.5)$ \\
\hline Top administration & $17(100.0)$ & $0(0.0)$ \\
\hline Top legal positions* & $3(100.0)$ & $0(0.0)$ \\
\hline Top business development/head branch positions & $20(100.0)$ & $0(0.0)$ \\
\hline Top asset, service, institutional effect positions* & $12(92.3)$ & $1(7.7)$ \\
\hline $\begin{array}{l}\text { Top PR and government/external relations } \\
\text { positions* }\end{array}$ & $10(90.9)$ & $1(9.1)$ \\
\hline TOTAL & $481(94.3)$ & $29(5.7)$ \\
\hline COMBINED TOTAL & $2669(95.5)$ & $125(4.5)$ \\
\hline
\end{tabular}

*Not included in rank order as it is too small a sample. 
Table 2: Sector-Business Leaders in Oman Companies by Gender

\begin{tabular}{|l|l|l|l|l|}
\hline Category & $\begin{array}{l}\text { No. of } \\
\text { Companies } \\
(\%)\end{array}$ & $\begin{array}{l}\text { Compan } \\
\mathbf{y} \\
\text { Employe } \\
\text { e Count }\end{array}$ & $\begin{array}{l}\text { Male } \\
\text { Leaders } \\
\text { No. (\%) }\end{array}$ & $\begin{array}{l}\text { Female } \\
\text { Leaders } \\
\text { No. (\%) }\end{array}$ \\
\hline $\begin{array}{c}\text { Industry (agriculture, construction, } \\
\text { manufacturing, mining and metal, } \\
\text { oil and gas, power and utilities) }\end{array}$ & $61(50)$ & 169931 & $1177(97.1)$ & $35(2.9)$ \\
\hline $\begin{array}{c}\text { Sales (consumer goods, real estate, } \\
\text { retail) }\end{array}$ & $7(5.7)$ & 14195 & $166(97.6)$ & $4(2.4)$ \\
\hline $\begin{array}{c}\text { Pseudo Services (education, } \\
\text { government, healthcare, services, } \\
\text { legal) }\end{array}$ & $2(1.6)$ & 800 & $33(94.3)$ & $2(5.7)$ \\
\hline $\begin{array}{c}\text { Finance (financial services, Islamic } \\
\text { finance) }\end{array}$ & $11(9.0)$ & 13904 & $379(92.7)$ & $30(7.3)$ \\
\hline $\begin{array}{c}\text { Hospitality (leisure and tourism, } \\
\text { food and beverage) }\end{array}$ & $24(19.7)$ & 45179 & $442(95.9)$ & $19(4.1)$ \\
\hline Technology (IT, media, telecom) & $3(2.5)$ & 4129 & $115(95.8)$ & $5(4.2)$ \\
\hline Transport (transport) & $14(11.5)$ & 43176 & $357(92.2)$ & $30(7.8)$ \\
\hline $\begin{array}{l}\text { Missing: 0 } \\
\text { TOTAL }\end{array}$ & 122 & 291314 & $2669(95.5)$ & $125(4.5)$ \\
\hline
\end{tabular}

Table 3: Number of Company Employees_-Business Leaders in Oman Companies by Gender

\begin{tabular}{|l|l|l|l|l|}
\hline Category & $\begin{array}{l}\text { No. of } \\
\text { Companie } \\
\text { s } \\
\text { Analyzed }\end{array}$ & $\begin{array}{l}\text { Employe } \\
\text { e Total }\end{array}$ & $\begin{array}{l}\text { Male } \\
\text { Leaders } \\
\text { No. }(\%)\end{array}$ & $\begin{array}{l}\text { Female } \\
\text { Leaders } \\
\text { No. (\%) }\end{array}$ \\
\hline 300-499 employee companies & $36(29.8)$ & 13034 & $662(95.3)$ & $33(4.7)$ \\
\hline 500-999 employee companies & $27(22.3)$ & 17160 & $590(97.4)$ & $16(2.6)$ \\
\hline 1000-2499 employee companies & $22(18.2)$ & 31129 & $538(92.9)$ & $41(7.1)$ \\
\hline 2500-4999 employee companies & $18(14.9)$ & 63491 & $453(97.6)$ & $11(2.4)$ \\
\hline 5000+ employee companies & $18(14.9)$ & 166500 & $422(94.6)$ & $24(5.4)$ \\
\hline Missing: 1 TOTAL & 121 & 291314 & $2665(95.5)$ & $125(4.5)$ \\
\hline
\end{tabular}


Table 4: Ownership —-Business Leaders in Oman Companies by Gender

\begin{tabular}{|c|c|c|c|c|}
\hline \multirow[t]{2}{*}{ Category } & \multicolumn{2}{|c|}{ Private } & \multicolumn{2}{|c|}{ Public } \\
\hline & $\begin{array}{l}\text { Male } \\
\text { No. }(\%)\end{array}$ & $\begin{array}{l}\text { Female } \\
\text { No. }(\%)\end{array}$ & $\begin{array}{l}\text { Male } \\
\text { No. }(\%)\end{array}$ & $\begin{array}{l}\text { Female } \\
\text { No. }(\%)\end{array}$ \\
\hline \multicolumn{5}{|l|}{ SENIOR COMPANY LEADERS } \\
\hline Board members & $249(92.6)$ & $20(7.4)$ & $248(96.5)$ & $9(3.5)$ \\
\hline Top management & $593(97.5)$ & $15(2.5)$ & $342(96.1)$ & $14(3.9)$ \\
\hline Key officers & $4(100.0)$ & $0(0.0)$ & $4(100.0)$ & $0(0.0)$ \\
\hline $\begin{array}{l}\text { Regional/branch/division/unit heads } \\
\text { and managers }\end{array}$ & $86(98.9)$ & $1(1.1)$ & $13(100.0)$ & $0(0.0)$ \\
\hline Chief officers - CEO, CFO, COO & $78(100.0)$ & $0(0.0)$ & $57(98.3)$ & $1(1.7)$ \\
\hline General managers & $108(98.2)$ & $2(1.8)$ & $49(94.2)$ & $3(5.8)$ \\
\hline Vice presidents & $3(100.0)$ & $0(0.0)$ & $12(100.0)$ & $0(0.0)$ \\
\hline Directors & $168(87.5)$ & $24(12.5)$ & $174(96.1)$ & $7(3.9)$ \\
\hline TOTAL & $1289(95.4)$ & $62(4.6)$ & $899(96.4)$ & $34(3.6)$ \\
\hline \multicolumn{5}{|l|}{ TOP DEPARTMENT LEADER } \\
\hline Department heads & $31(93.9)$ & $2(6.1)$ & $32(82.1)$ & $7(17.9)$ \\
\hline $\begin{array}{l}\text { Top positions in finance, banking, } \\
\text { investor relations, and wealth }\end{array}$ & $57(98.3)$ & $1(1.7)$ & $27(96.4)$ & $1(3.6)$ \\
\hline Top HR positions & $46(90.2)$ & $5(9.8)$ & $15(88.2)$ & $2(11.8)$ \\
\hline Top IT/data/information positions & $27(100.0)$ & $0(0.0)$ & $10(100.0)$ & $0(0.0)$ \\
\hline $\begin{array}{l}\text { Top marketing, sales, communication, } \\
\text { corporate affairs, brand, and } \\
\text { circulation }\end{array}$ & $33(84.6)$ & $6(15.4)$ & $19(95.0)$ & $1(5.0)$ \\
\hline $\begin{array}{l}\text { Top operations, turbocharge, strategy, } \\
\text { and commercial positions }\end{array}$ & $74(100.0)$ & $0(0.0)$ & $41(97.6)$ & $1(2.4)$ \\
\hline Top project management positions & $6(85.7)$ & $1(14.3)$ & $1(100.0)$ & $0(0.0)$ \\
\hline Top administration & $16(100.0)$ & $0(0.0)$ & $1(100.0)$ & $0(0.0)$ \\
\hline Top legal positions & $1(100.0)$ & $0(0.0)$ & $2(100.0)$ & $0(0.0)$ \\
\hline $\begin{array}{l}\text { Top business development/head } \\
\text { branch positions }\end{array}$ & $16(100.0)$ & $0(0.0)$ & $4(100.0)$ & $0(0.0)$ \\
\hline $\begin{array}{l}\text { Top asset, service, institutional effect } \\
\text { positions* }\end{array}$ & $5(100.0)$ & $0(0.0)$ & $7(87.5)$ & $1(12.5)$ \\
\hline $\begin{array}{l}\text { Top PR and government/external } \\
\text { relations positions }\end{array}$ & $5(83.3)$ & $1(16.7)$ & $5(100.0)$ & $0(0.0)$ \\
\hline TOTAL & $317(95.2)$ & $16(4.8)$ & $164(92.7)$ & $13(7.3)$ \\
\hline
\end{tabular}

*87 private companies $(71.3 \%)$ and 35 publicly traded companies $(28.7 \%)$ 


\section{References}

Abugideiri, H. (2012), “A labor of love: Making space for midwives in Gulf history”, in ElAzhary Sonbol, A. (Ed.), Gulf Women, Syracuse University Press, Syracuse, NY, pp. $167-201$.

Al-Barwani, T., Chapman, D.W. and Ameen, H. (2009), "Strategic brain drain: Implications for higher education in Oman”, Higher Education Policy, Vol. 22 No. 4, pp. 415-32.

Al-Hamadi, A., Budhwar, P.S. and Shipton, H. (2007), "Management of human resources in Oman”, International Journal of Human Resource Management, Vol. 18 No. 1, pp. $100-13$.

Al-Harthi, H.K. (2011), "University student perceptions of the relationship between university education and the labour market in Egypt and Oman”, Prospects, Vol. 41 No. 4, pp. 535-51.

Al-Lamki, S.M. (2002), "Higher education in the Sultanate of Oman: The challenge of access, equity and privatization", Journal of Higher Education Policy and Management, Vol. 24 No. 1, pp. 75-86.

Al-Lamki, S.M. (2005), "The role of the private sector in Omanization: The case of the banking industry in the Sultanate of Oman", International Journal of Management, Vol. 22 No. 2, pp. 176-88.

Al-Lamky, S. (2006), "Feminizing leadership in Arab societies: The perspectives of Omani female leaders", Women in Management Review, Vol. 22 No. 1, pp. 49-67.

Al-Qudsi, S.S. (1998), "Labour participation of Arab women: Estimates of the fertility to labour supply link", Applied Economics, Vol. 30 No. 7, pp. 931-41. 
Al-Sadi, R., Belwal, R. and Al-Badi, R. (2011), "Woman entrepreneurship in the Al-Batinah region of Oman: An identification of the barriers", Journal of International Women's Studies, Vol. 12 No. 3, pp. 58-75.

Al-Sayegh, F. (2012), "Women of the Gulf during the first half of the twentieth century: A comparative study of American missionary archives and local memory", in El-Azhary Sonbol, A. (Ed), Gulf Women, Syracuse University Press, Syracuse, NY, pp. 241-77. Budhwar, P.S., Al-Yahmadi, S. and Debrah, Y. (2002), "Human resource development in the Sultanate of Oman”, International Journal of Training and Development, Vol. 6 No. 3, pp. 198-215.

Chatty, D. (2000), "Women working in Oman: Individual choice and cultural constraints", International Journal of Middle East Studies, Vol. 32 No. 2, pp. 241-54.

Common, R. (2011), “Barriers to developing 'leadership' in the Sultanate of Oman”, International Journal of Leadership Studies, Vol. 6 No. 2, pp. 215-18.

Common, R., (2012), “Leadership in the Sultanate of Oman”, in Metcalfe, B.D. and F. Mimouni (Eds), Leadership Development in the Middle East, Edward Elgar, Cheltenham, UK, pp. 152-68.

CountryWatch, Inc. (2012), “Status of women”, Oman Country Review, pp. 136-39.

Curtiss, R.H. (1999), “Revisiting ‘unknown Oman': Integrating women part and parcel of 'Omanization' of nation's work force”, The Washington Report on Middle East Affairs, Vol. 18 No. 2, pp. 65-66.

Davis, P.J. (2012), “The global training deficit: The scarcity of formal and informal professional development opportunities for women entrepreneurs", Industrial and Commercial Training, Vol. 44 No. 1, pp. 19-25. 
Dechant, K. and Al-Lamky, A. (2005), “Toward an understanding of Arab women entrepreneurs in Bahrain and Oman", Journal of Developmental Entrepreneurship, Vol. 10 No. 2, pp. 123-40.

Dubai Women Establishment. (2011), Arab Women: Leadership Outlook 2009-2011, available at http://www.pwc.com/en_GX/gx/women-at-pwc/assets/Arab-WomenLeadership-Outlook.pdf (accessed 13 January 2013).

Economist Intelligence Unit Limited (Nov., 2010), "Country report, Oman”, Monthly Review: The Political Scene, pp. 10-12.

Elnaggar, A. (2008), “Towards gender equal access to ICT”, Information Technology for Development, Vol.14 No. 4, pp. 280-93.

Ghailani, J.S. and Khan, S.A. (2004), "Quality of secondary education and labour market requirement”, Journal of Services Research, Vol. 4 No. 1, pp. 161-72.

Goveas, S. and Aslam, N. (2011), "A role and contributions of women in the Sultanate of Oman”, International Journal of Business and Management, Vol. 6 No. 3, pp. 23239.

Harris, H. and Kumra, S. (2000), “International manager development: Cross-cultural training in highly diverse environments", Journal of Management Development, Vol. 19 No. 7, pp. $602-14$.

Hausmann, R., Tyson, L.D. and Zahidi, S. (2011), “The Global Gender Gap report, 2011”, available at: http://reports.weforum.org/global-gender-gap-2011/ (accessed 13 January 2013).

Hawkamah, The Institute for Corporate Governance (Nov. 2012), "Diversity and the boardroom: The case for women in regional (UAE) boards", White Paper 4, pp. 1-9. 
Hutchings, K., Metcalfe, B.D., and Cooper, B.K. (2010), "Exploring Arab Middle Eastern women's perceptions of barriers to, and facilitators of, international management opportunities", The International Journal of Human Resource Management, Vol. 21 No. 1, pp. 61-83.

ILO (2010), “Sultanate of Oman: Decent Work Country Programme 2010 13”, available at: http://www.ilo.org/public/english/bureau/program/dwcp/download/oman.pdf (accessed 13 January 2013).

Karabenick, S.A. and Moosa, S. (2005), “Culture and personal epistemology: U.S. and Middle Eastern students' beliefs about scientific knowledge and knowing”, Social Psychology of Education, Vol. 8 No. 4, pp. 375-93.

Kemp, L.J., Madsen, S.R. and El-Saidi, M. (2013), "The current state of female leadership in the United Arab Emirates”, Journal of Global Responsibility, Vol. 4 No. 1, pp. 99112.

Khan, G.M. and Almoharby, D. (2007), “Towards enhancing entrepreneurship development in Oman", Journal of Enterprising Culture, Vol. 15 No. 4, pp. 371-92.

Khan, S.A. (2010), "Managing performance: The case of an Omani oil company”, Vision: The Journal of Business Perspective, Vol. 14 No. 4, pp. 285-93.

Kuehn, K.W. and Al-Busaidi, Y. (2000), “A difference of perspective: An exploratory study of Omani and expatriate values and attitudes", International Journal of Commerce and Management, Vol. 10 No. 1, pp. 74-90.

Lalji, N. (2006), “Middle East: Labor Law Matters”, Harvard International Review, Vol. 28 No. 3, pp. 12-13. 
Maben, J., Al-Thowini, K., West, E. and Rafferty, A.M. (2010), “Uneven development: Comparing the indigenous health care workforce in Saudi Arabia, Bahrain and Oman”, International Journal of Nursing Studies, Vol. 47 No. 3, pp. 392-96.

McElwee, G. and Al-Riyami, R. (2003), "Women entrepreneurs in Oman: Some barriers to success", Career Development International, Vol. 8 No. 7, pp. 339-46.

Mellahi, K., Guermat, C., Frynas, J.G. and Al-Bortamani, H. (2003), "Motives for FDI in Gulf Cooperation Council States: The case of Oman", Thunderbird International Business Review, Vol. 45, pp. 431-46.

Mernissi, F. (2003), Beyond the Veil: Male-Female Dynamics in a Modern Muslim Society, Saqi Books, London.

Metcalfe, B.D. (2006), "Exploring cultural dimensions of gender and management in the Middle East”, Thunderbird International Business Review, Vol. 48 No. 1, pp. 93-107. Ministry of Manpower. (2012), "Sultanate of Oman. Omani labour law part five. Employment of juveniles and women chapter two. Employment of women”, available at: http://www.manpower.gov.om/en/law_women_juveniles.asp (accessed 26 November 2012).

Ministry of the National Economy. (1996), "Second long term development strategy (19962020)”, Sultanate of Oman Supreme Council for Planning National Center for Statistics and information, available at: http://www.moneoman.gov.om/loader.aspx? view=planning-ds-sltdsandtype=plan (accessed 5 February, 2013).

National Center for Statistics and Information, (2010), "General census of population, housing and establishments, final results," Sultanate of Oman, Supreme Council for Planning, available at: www.omancensus.net (accessed 5 February, 2013). 
National Center for Statistics and Information (2011a), "Facts and figures 2011”, Sultanate of Oman, Supreme Council for Planning, available at: http://www.moneoman.gov.om/ viewPublication. aspx?id=833 (accessed 5 February 2013).

National Center for Statistics and Information. (2011b), "Sultanate of Oman, Supreme Council for Planning Statistical year book (2011)" available at: http:// www.ncsi.gov.om/book/SYB2011/index.htm (accessed 5 February 2013).

Neal, M., Finlay, J. and Tansey, R. (2005), “"My father knows the minister”: A comparative study of Arab women's attitudes towards leadership authority", Women in Management Review, Vol. 20 No. 7/8, pp. 478-97.

Neal, M. (2010),”When Arab-expatriate relations work well: Diversity and discourse in the Gulf Arab workplace”, Team Performance Management, Vol. 16 No. 5/6, pp. 242-66.

Porcaro, D. (2011), “Applying constructivism in instructivist learning cultures”, Multicultural Education \& Technology Journal, Vol. 5 No. 1, pp. 39-54.

Robertson, C., Al-Khatib, J.A., Al-Habib, M. and Lanoue, D. (2001), "Beliefs about work in the Middle East and the convergence versus divergence of values", Journal of World Business, Vol. 36 No. 3, pp. 223-44.

Shaw, K.E. (2001), "Human capital formation in the Gulf and MENA region", Mediterranean Journal of Educational Studies, Vol. 6 No. 1, pp. 91-106.

Syed, J. (2010), “An historical perspective on Islamic modesty and its implications for female employment", Equality, Diversity and Inclusion: An International Journal, Vol. 29 No. 2, pp.150-66.

Tlaiss, H. and Kauser, S. (2011), "The impact of gender, family, and work on the career advancement of Lebanese women managers", Gender in Management: An International Journal, Vol. 26 No. 1, pp. 8-36. 
Zawya (2013), "Middle East Business", available at http://www.zawya.com/ (accessed 14

February 2013). 